\title{
PERLINDUNGAN HUKUM TERHADAP DEBITOR YANG WANPRESTASI DALAM PERJANJIAN UTANG PIUTANG DARI ANCAMAN HUKUM PIDANA
}

\author{
Muhammad Gary Gagarin Akbar \\ Zarisnov Arafat
}

\section{Universitas Buana Perjuangan Karawang}

\author{
Email: gary.akbar@ubpkarawang.ac.id \\ zarisnov@ubpkarawang.ac.id
}

\begin{abstract}
Abstrak
Perjanjian merupakan perbuatan hukum yang paling sering kita lihat dalam kehidupan sehari-hari, khususnya perjanjian utang piutang. Dari masyarakat kelas atas sampai kelas bawah pernah melakukan perjanjian utang piutang untuk menutupi kebutuhan hidupnya. Dalam pelaksanaan perjanjian utang piutang mengandung resiko bahwa adanya kemungkinan terjadinya wanprestasi. Kasus wanprestasi yang dilakukan debitor dalam perjanjian utang piutang membawa masalah baru manakala kreditor yang merasa dirugikan melaporkan debitor kepada pihak kepolisian karena ketidakmampuannya membayar utang. Debitor harus mendapatkan perlindungan hukum dari ancaman pidana karena masalah perjanjian merupakan masalah hukum perdata yang jika terjadi permasalahan harus diselesaikan dengan jalur perdata pula. Lokasi dilakukannya penelitian ini yakni di beberapa wilayah Kabupaten Karawang dan Polres Karawang sebagai tempat dalam memperoleh data-data terkait kasus wanprestasi utang piutang. Metode yang digunakan dalam penelitian ini adalah penelitian lapangan (field research) dengan cara melakukan observasi, catatan lapangan, dan wawancara terhadap pihak terkait di lokasi penelitian tersebut. Hasil penelitian ini menjelaskan mengenai perlindungan hukum terhadap debitor wanprestasi apabila debitor pada saat melakukan negosiasi sebelum tercapainya kesepakatan melakukan tipu daya seperti nama palsu ataupun martabat palsu sebagaimana yang tercantum dalam Pasal 378 KUHP. Kemudian pola penyelesaian sengketa yang ideal dalam sengketa utang piutang adalah melalui negosiasi agar tercapainva win-win solution.
\end{abstract}

Kata Kunci : Debitor, Perjanjian, Wanprestasi.

\begin{abstract}
The agreement is a legal act that we see most often in everyday life, especially the debt agreement. From the upper class to the lower classes, they have made debt agreement to cover their life needs. In the implementation of the loan agreement, there is a risk that there is a possibility of default. Cases of breach of agreement carried out by debtors in the loan agreement bring new problems when creditors who feel disadvantaged report debtors to the police because of their inability to pay debts. Debtors must get legal protection from criminal threats because the issue of agreement is a matter of civil law which if a problem occurs must also be solved by civil lines. The location of this research is in several areas of Karawang Regency and Karawang Police Station as a place to obtain data regarding cases of breach of agreement on accounts payable. The method used in this study is field research by conducting observations, field research, and interviews with related parties at the location of the research. The results of this study explain legal protection against debtors of breach of agreement if the debtor at the time of negotiation before reaching an agreement commits deception such as false names or false dignity as stated in Article 378 of the Criminal Code. Then the ideal dispute resolution pattern in debt debt disputes is through negotiations to achieve a win-win solution.
\end{abstract}

Keywords: Debtor, Agreement, Breach of contract 


\section{PENDAHULUAN}

Istilah kontrak berasal dari bahasa Inggris, yaitu contracts. Sedangkan dalam bahasa Belanda, disebut overeenkomst (perjanjian). ${ }^{1}$ Pada prinsipnya kontrak terdiri dari satu atau serangkaian janji yang dibuat para pihak dalam kontrak. Esensi dari kontrak itu sendiri adalah kesepakatan (agreement). Atas dasar itu, Subekti mendefinisikan kontrak sebagai peristiwa dimana seseorang berjanji kepada orang lain di mana dua orang saling berjanji untuk melaksanakan sesuatu. ${ }^{2}$ Pasal 1313 KUHPerdata menyatakan bahwa suatu perjanjian adalah suatu perbuatan yang terjadi antara satu orang atau lebih mengikatkan dirinya kepada satu orang atau lebih lainnya

Perjanjian utang-piutang merupakan hal yang biasa terjadi di dalam pergaulan masyarakat. Struktur masyarakat yang berbeda satu sama lain membuat praktik utang-piutang tidak bisa dihindari. Utang-piutang berkonotasi pada uang dan barang yang dipinjam dengan kewajiban membayar kembali apa yang sudah diterima dengan nilai yang sama. Utang-piutang yaitu memberikan sesuatu kepada orang lain dengan perjanjian dia akan membayar dengan yang semestinya. Pengertian utang piutang dapat disamakan dengan pinjam meminjam. Definisi pinjammeminjam menurut Pasal 1754 KUHPerdata

1 Salim, Teori dan Teknik Penyusunan Kontrak, Sinar Grafika, Jakarta 2015, hlm.25.

2 Ridwan Khairandy, Hukum Kontrak Indonesia Dalam Perspektif Perbandingan (bagian Pertama), FH UII Press, Yogyakarta, 2013, hlm.57 adalah suatu perjanjian dengan mana pihak yang satu memberikan kepada pihak yang lain suatu jumlah tertentu barang-barang yang habis karena pemakaian, dengan syarat bahwa pihak yang terakhir ini akan mengembalikan sejumlah uang yang sama dengan jenis dan mutu yang sama pula.

Berbicara mengenai utang-piutang bukanlah hal yang asing di telinga semua orang, karena setiap hari selalu ada saja masalah yang satu ini. Utang piutang merupakan perjanjian antara pihak yang satu dengan pihak yang lainnya dan objek yang diperjanjikan pada umumnya adalah uang. Kedudukan pihak yang satu sebagai pihak yang memberikan pinjaman (kreditor), sedang pihak yang lain adalah pihak yang menerima pinjaman uang tersebut (debitor). Dimana uang yang dipinjam itu akan dikembalikan dalam jangka waktu tertentu sesuai dengan yang diperjanjikannya. ${ }^{3}$

\section{PERMASALAHAN}

Permasalahan mengenai perjanjian utang piutang ini dapat dikatakan sesuatu hal yang rumit di dalam praktik. Biasanya debitor yang membutuhkan dana datang kepada seseorang yang dianggap memiliki kemampuan ekonomi yang berkecukupan. Ketika seseorang datang kepada orang yang memiliki dana untuk meminjam uang, maka

\footnotetext{
3 Gatot Supramono, Perjanjian Utang Piutang, Kencana Prenada Media Group, Jakarta, 2013, hlm. 9
} 
biasanya dibuat suatu perjanjian. Namun beberapa praktik ada juga yang hanya dibuatkan suatu kuitansi yang isinya berupa jumlah uang yang dipinjam dan tanda tangan penerima uang dan pihak yang memberikan pinjaman.

Di dalam suatu pelaksanaan perjanjian tentu saja tidak selamanya sesuai dengan halhal yang telah disepakati dalam perjanjian. Seringkali para pihak tidak dapat melaksanakan kewajibannya sebagaimana yang telah diperjanjikan. Kegagalan dalam melaksanakan kewajiban dalam perjanjian disebut wanprestasi. Wanprestasi dalam perjanjian utang piutang dapat dikatakan debitor tidak dapat mengembalikan uang yang telah dipinjam dalam jangka waktu yang telah ditetapkan.

Ketika debitor tidak dapat mengembalikan uang atau menepati janjinya, maka kreditor akan menagih kepada debitor. Faktor ekonomi yang debitor yang memang sedang tidak stabil menjadi salah satu sebab alasan debitor tidak dapat memenuhi kewajibannya. Dalam beberapa kasus yang terjadi di Kabupaten Karawang, pihak kreditor yang merasa kecewa terhadap debitor serta kesulitan untuk mendapatkan pengembalian uang dari debitor, ada beberapa yang sampai melaporkan debitor kepada pihak kepolisian. Hal ini menarik untuk diteliti karena pada dasarnya permasalahan utang piutang adalah masalah perdata tapi di dalam praktik masih ada masyarakat yang memilih menyelesaikan kasus ini melalui jalan pidana.

\section{METODE PENELITIAN}

Penelitian ini menggunakan metode pendekatan yuridis sosiologis yaitu untuk mengevaluasi keterkaitan aspek-aspek empiris. Metode penelitian yang dilakukan dalam program ini diawali dengan pengumpulan data awal metode deskriptif. Informasi awal yang sudah didapatkan selanjutnya akan dicari akar permasalahannya lalu dijabarkan dalam bentuk teori dengan mendapatkan dukungan bahan dari informasi kepustakaan terkait yang bersifat relevan. Program penelitian ini akan melakukan penelitian langsung terhadap lembaga atau obyek penelitiannya (penelitian lapangan).

Sumber data merupakan asal dari mana data penelitian dapat diperoleh. Sumber data yang dipergunakan dalam penelitian ini meliputi:

a) Data Primer, merupakan data pokok yang diperlukan dalam penelitian yang berasal dari responden dan informan dan merupakan sumber data utama yang diperoleh peneliti dari :

- Responden ialah merupakan sumber data yang berupa orang dalam penelitian ini yang dijadikan responden kreditor dan debitor atau orang yang melakukan perjanjian utang piutang dan Polres Karawang. 
- Informan ialah orang yang dimanfaatkan untuk memberikan tentang situasi dan kondisi latar penelitian. Sehingga dalam penelitian ini yang menjadi informan adalah masyarakat dan Polres Karawang.

b) Data Sekunder, merupakan data yang menunjang data primer dan merupakan pelengkap bagi data primer. Data sekunder ini merupakan data dari penelitian kepustakaan, yang terdiri dari 3 (tiga) bahan hukum yakni :

- Bahan hukum primer adalah bahan hukum yang sifatnya mengikat berupa peraturan perundangundangan yang berlaku dan ada kaitannya dengan permasalahan yang dibahas, antara lain Kitab Undang-Undang Hukum Perdata (KUH Perdata); Undang-Undang Nomor 30 Tahun 1999 tentang Arbitrase dan Alternatif Penyelesaian Sengketa.

- Bahan hukum sekunder adalah bahan hukum yang sifatnya menjelaskan bahan hukum primer, dimana bahan hukum sekunder berupa literaur, hasil karya penelitian (jurnal, karya ilmiah).

- Bahan hukum tersier adalah bahan hukum sebagai pelengkap dari kedua bahan hukum sebelumnya, yang berupa kamus hukum dan kamus bahasa Indonesia.

Teknik pengumpulan data dimaksudkan sebagai cara untuk memperoleh data dalam penelitian. Teknik pengumpulan data yang digunakan dalam penelitian ini antara lain melakukan wawancara; melakukan observasi; dan mengumpulkan dokumen-dokumen serta melakukan studi pustaka yang berkaitan dengan permasalahan yang dicari dalam penelitian ini.

Analisis data penelitian menggunakan data kualitatif model interaktif yang berlangsung terus menerus dan berkelanjutan. Analisis model interaktif melalui berbagai alur kegiatan melalui langkah-langkah sebagai berikut :

a) Pengumpulan Data

Pengumpulan data ialah mencari dan mengumpulkan data yang diperlukan yang dilakukan terhadap berbagai jenis dan bentuk apa yang ada di lapangan kemudian data tersebut dicatat. Pengumpulan data ini dilakukan berkaitan dengan data penelitian yang ada di lapangan yaitu peneliti melakukan wawancara kepada petugas Polres Karawang yang melakukan penyelidikan terhadap kasus wanprestasi perjanjian utang piutang.

b) Penyajian Data

Penyajian data ialah sekumpulan informasi tersusun yang memberi kemungkinan adanya penarikan kesimpulan 
dan pengambilan tindakan. Data yang diperoleh dari obyek penelitian dari data primer maupun sekunder akan disusun secara sistematis dan disajikan dalam bentuk laporan penelitian secara kualitatif yaitu berdasarkan konsep teori, peraturan perundang-undangan tentang perlindungan hukum terhadap debitor wanprestasi dari ancaman hukum pidana.

c) Menarik Kesimpulan

Kesimpulan ialah suatu tinjauan ulang pada catatan lapangan atau kesimpulan dapat ditinjau sebagaimana yang muncul dari data yang harus diuji kebenarannya, kekokohan dan kecocokannya yaitu mencapai validitasnya. Pengumpulan data, reduksi data, penyajian data dan menarik simpulan sebagai suatu yang berkaitan pada saat sebelum, selama dan sesudah pengumpulan data berlangsung. Dalam hal ini peneliti mengoreksi kembali hasil penelitian dengan catatan yang terdapat di lapangan selama penelitian. Setelah data tersebut sesuai, maka dapat ditarik kesimpulan dari setiap item yang ada. tahapan analisis data kualitatif diatas melibatkan beberapa komponen data interaksi yang merupakan suatu proses siklus dalam melakukan analisis data.

\section{PEMBAHASAN}

A. Perlindungan Hukum Terhadap Debitor Wanprestasi dalam Perjanjian Utang Piutang dari Ancaman Hukum Pidana
Perjanjian utang piutang memang tidak kita temukan di dalam KUHPerdata. Namun istilah tersebut dapat disamakan dengan perjanjian pinjam meminjam. Ketentuan pinjam meminjam terdapat di dalam Pasal 1754 KUHPerdata. Pinjam meminjam adalah suatu perjanjian dengan mana pihak yang satu memberikan kepada pihak yang lain suatu jumlah tertentu barang-barang yang habis karena pemakaian, dengan syarat bahwa pihak yang terakhir ini akan mengembalikan sejumlah uang yang sama dengan jenis dan mutu yang sama pula. ${ }^{4}$

Pada dasarnya suatu perjanjian atau kontrak merupakan suatu hal yang wajib dipenuhi oleh para pihak. hal ini ditegaskan dengan salah satu asas hukum yang ada di dalam hukum kontrak, yaitu asas pascta sunt servanda. Asas pacta sunt servanda menyatakan bahwa kesepakatan para pihak itu mengikat sebagaimana layaknya undangundang bagi para pihak yang membuatnya. Selain itu di dalam hukum kontrak juga terdapat asas iktikad baik. asas iktikad baik menekankan bahwa dalam pelaksanaan kontrak para pihak harus benar-benar melaksanakan prestasinya sesuai dengan kesepakatan.

Namun di dalam praktik seringkali debitor melanggar isi perjanjian yang telah disepakati (wanprestasi). unsur-unsur wanprestasi antara lain debitor sama sekali

${ }^{4}$ Subekti, Aneka Perjanjian, Citra Aditya Bakti, Bandung, 2014, hlm. 125 
tidak berprestasi, debitor keliru berprestasi, atau debitor terlambat berprestasi Permasalahan terkait dengan utang piutang memang sangat sering terjadi di masyarakat. Masyarakat yang ada di Kabupaten Karawang khususnya ternyata sangat sering melakukan perjanjian utang piutang, baik secara lisan maupun secara tertulis. Untuk jumlah yang kecil biasanya hanya melalui perjanjian secara lisan. Di dalam perjanjian utang piutang akan menjadi kompleks jika debitor tidak menepati perjanjian yang telah disepakati bersama. Debitor melakukan wanprestasi dari hasil wawancara dengan beberapa masyarakat, mengatakan bahwa memang kondisi ekonomi mereka yang mengakibatkan tidak dapat mengembalikan uang yang dipinjam sesuai dengan jangka waktu yang telah ditentukan. Awalnya mereka meminjam uang karena terdesak kebutuhan sehingga terpaksa meminjam uang kepada orang lain. Namun sebagian lagi meminjam uang untuk menjalankan usaha atau berbisnis.

Ketika masyarakat melakukan wanprestasi, biasanya mereka akan meminta perpanjangan waktu agar dapat melunasi atau mengembalikan uang tersebut. Fakta di lapangan tidak semua kreditor dapat menerima alasan yang diajukan oleh debitor. Bahkan kreditor ketika menuntut pengembalian uang kepada debitor tidak jarang mengancam akan melaporkan hal ini kepada pihak kepolisian. Sehingga masyarakat menjadi takut dan khawatir jika akan dipenjara akibat tidak dapat membayar utang.

Kemudian data yang ada di Polres Karawang terkait dengan pelaporan terhadap debitor yang tidak dapat membayar utang memang benar adanya walaupun jumlahnya hanya berkisar kurang lebih 10 laporan untuk tahun 2017 ini hingga bulan Oktober. Ada kreditor yang membuat laporan kepada pihak kepolisian karena uangnya Rp. 400.000.000,(empat ratus juta rupiah) tidak dikembalikan oleh kreditor. Kemudian ada juga yang membuat laporan karena uangnya puluhan juta rupiah belum dikembalikan oleh kreditor. Ketika pihak kepolisian mendapat laporan dari kreditor tentu saja tidak akan langsung diproses, tetapi pihak kepolisian akan melakukan penyelidikan terlebih dahulu apakah kasus tersebut termasuk kasus perdata atau kasus pidana. Apabila kasus tersebut murni utang-piutang maka kasus tersebut tidak akan dilanjutkan oleh pihak kepolisian.

Pelaporan yang dilakukan oleh beberapa kreditor kepada pihak kepolisian terhadap debitor tentu saja menyebabkan kegaduhan di lingkungan masyarakat. Masyarakat tentunya takut jika harus berurusan dengan polisi karena tidak dapat membayar utang. Dari data yang telah didapatkan, maka pertanyaan yang muncul dari kalangan masyarakat apakah debitor yang wanprestasi dapat dikenakan tindak pidana? 
Di dalam suatu perjanjian, ada 4 (empat) syarat yang harus dipenuhi seperti yang terdapat pada Pasal 1320 KUHPerdata, yaitu:

1. Kata sepakat dari para pihak;

Suatu kontrak akan sah apabila para pihak sepakat dengan segala hal yang terdapat dalam suatu perjanjian. Pada dasarnya kata sepakat adalah pertemuan atau persesuaian kehendak antara para pihak. Dalam pembentukan kata sepakat tersebut tidak boleh mengandung unsur penipuan, penyalahgunaan keadaan, paksaan, dan kekeliruan.

2. Kecakapan untuk membuat suatu perikatan;

Kecakapan para pihak dalam membuat suatu perikatan berkaitan dengan kedewasaan seseorang dan cakap atau tidak para pihak tersebut. Seseorang yang telah dewasa tetapi dianggap tidak cakap melakukan perikatan apabila gila, dungu, mata gelap, dan lemah akal. Mereka yang masuk kategori seperti itu akan berada di bawah pengampuan.

3. Suatu hal tertentu;

Suatu hal tertentu adalah berkaitan dengan kewajiban debitor dan hak kreditor. Ini berarti bahwa hal tertentu adalah apa yang diperjanjian, yakni hak dan kewajiban para pihak.

4. Suatu sebab yang halal;

Suatu sebab yang halal sering juga disebut dengan kausa hukum yang halal yang berarti alasan yang diperbolehkan. Halal disini maksudnya adalah kausa hukum yang ada tidak bertentangan dengan peraturan perundang-undangan atau

ketertiban umum atau kesusilaan.

Syarat pertama dan kedua dikatakan sebagai syarat subjektif, artinya apabila tidak terpenuhi maka perjanjian dapat dibatalkan. Kemudian syarat ketiga dan keempat dikatakan syarat objektif, artinya perjanjian tersebut batal demi hukum jika syaratnya tidak terpenuhi.

Terkait dengan pertanyaan yang muncul dari masyarakat apakah seseorang (kreditor) dapat melaporkan orang lain (debitor) kepada pihak kepolisian atas dasar tidak dapat membayar utang, pada dasarnya tidak ada ketentuan yang melarang hal tersebut. Namun, di dalam Pasal 19 ayat (2) UU No. 39 Tahun 1999 tentang Hak Asasi Manusia dapat menjadi rujukan. UU HAM menyatakan bahwa tidak seorang pun atas putusan pengadilan boleh dipidana penjara atau kurungan berdasarkan atas alasan ketidakmampuan untuk memenuhi suatu kewajiban dalam perjanjian utang piutang. Ini artinya walaupun ada laporan, pengadilan tidak boleh mempidanakan seseorang karena tidak mampu membayar utang.

Di dalam praktik sebagaimana yang telah dijelaskan di atas, bahwa permasalahan utang piutang yang tidak dapat diselesaikan secara musyawarah, maka akan dilaporkan kepada pihak kepolisian dengan dasar Pasal 372 
KUHP tentang Penggelapan, dan Pasal 378 KUHP tentang Penipuan. Padahal substansi dari kedua Pasal tersebut adalah jelas berbeda dari suatu perjanjian yang merupakan perbuatan hukum perdata. Untuk dapat diproses secara pidana, maka harus ada perbuatan (actus reus) dan niat jahat (mens rea) dalam terpenuhinya unsur-unsur pasal pidana tersebut.

Di dalam KUHPerdata juga diatur mengenai penipuan, tepatnya terdapat di dalam Pasal 1328 KUHPerdata. Pasal tersebut menyatkan bahwa penipuan merupakan salah satu alsan untuk membatalkan kontrak atau perjanjian. Penipuan menurut pasal 1328 KUHPerdata dapat dijadikan alasan pembatalan perjanjian apabila penipuan yang dipakai oleh salah satu pihak sedemikian rupa sehingga secara nyata bahwa pihak lainnya tidak akan mengadakan perjanjian tanpa adanya tipu muslihat (niet zoude aangegaan). ${ }^{5}$ Untuk memahami tentang penipuan, maka Pasal 378 KUHP senantiasa menjadi rujukan.

Pasal 378 KUHP tentang Penipuan merupakan pasal yang paling sering digunakan oleh seseorang untuk melaporkan orang lain (debitor) kepada pihak kepolisian karena ketidakmampuannya membayar utang. Pasal 378 KUHP menyatakan bahwa "Barang siapa dengan maksud untuk menguntungkan diri sendiri atau orang lain secara melawan hukum, dengan memakai nama palsu atau

\footnotetext{
${ }^{5}$ Ridwan Khairandy, op.cit, hlm.223
}

martabat palsu, dengan tipu muslihat, ataupun rangkaian kebohongan, menggerakan orang lain untuk menyerahkan barang sesuatu kepadanya, atau supaya memberi utang maupun menghapuskan piutang, diancam karena penipuan dengan pidana penjara paling lama empat tahun". Berdasarkan bunyi pasal tersebut di atas, maka unsur-unsur penipuan adalah:

a. Dengan maksud untuk menguntungkan diri sendiri dengan melawan hukum;

b. Menggerakan orang untuk menyerahkan barang sesuatu atau supaya memberi utang maupun menghapuskan piutang;

c. Dengan menggunakan salah satu upaya atau cara penipuan (memakai nama palsu, martabat palsu, tipu muslihat, rangkaian kebohongan). Tipu Muslihat: Satochid Kartanegara mengemukakan, tipu muslihat ialah tindakan-tindakan yang sedemikian rupa, sehingga dapat menimbulkan kepercayaan orang atau memberi kesan pada orang yang digerakkan, seolah-olah keadaannya sesuai dengan kebenaran. ${ }^{6}$

Unsur yang ketiga atau poin c di atas yaitu mengenai cara adalah unsur pokok delik yang harus dipenuhi untuk mrngklasifikasikan

6 P.A.F. Lamintang dan Theo Lamintang, DelikDelik Khusus Kejahatan Terhadap Harta Kekayaan, Sinar Grafika, Jakarta, 2009, hlm. 167 
suatu perbuatan dikatakan sebagai penipuan. Kemudian hal tersebut dipertegas lagi dengan Yurisprudensi Mahkamah Agung No.1601.K/Pid/1990 tanggal 26 Juli 1990 yang intinya menyatakan bahwa unsur pokok delik penipuan yang terdapat di dalam Pasal 378 KUHP adalah terletak pada cara atau upaya yang telah digunakan oleh si pelaku delik untuk menggerakan orang lain agar menyerahkan sesuatu barang.

Berdasarkan penjelasan di atas, maka debitor baru dapat diproses secara pidana apabila dalam pembentukkan kata sepakat memenuhi unsur-unsur tentang penipuan. Apabila debitor tidak melakukan rangkaian kebohongan demi mendapatkan pinjaman utang kepada debitor atau benar-benar melalui proses yang wajar, maka debitor tidak dapat dituntut dengan ancaman pidana khususnya Pasal 378 KUHP tentang penipuan. Debitor akan terbebas dari ancaman hukuman pidana karena ketidakmampuannya dalam melaksanakan isi perjanjian. Secara hukum kreditor hanya dapat menyelesaikan persoalan ini melalui proses penyelesaian hukum perdata.

\section{A. Penyelesaian Kasus Wanprestasi}

Pada tahap pelaksanaan perjanjian, para pihak harus melaksanakan apa yang telah diperjanjikan atau apa yang telah menjadi kewajibannya dalam perjanjian tersebut. Kewajiban dalam memenuhi apa yang telah diperjanjikan itulah yang disebut dengan prestasi, sedangkan apabila salah satu pihak atau kedua pihak tidak melaksanakan kewajibannya sesuai dengan apa yang telah disepakati, maka itulah yang disebut wanprestasi. ${ }^{7}$ Pihak yang melakukan wanprestasi dalam suatu perjanjian dapat dituntut oleh pihak lain yang merasa dirugikan, namun pihak yang dituduh melakukan wanprestasi tersebut masih dapat melakukan pembelaan-pembelaan tertentu agar dia dapat terbebas dari pembayaran ganti rugi. ${ }^{8}$

Di dalam suatu perjanjian utang piutang, maka prestasi debitor adalah mengembalikan uang yang telah dipinjam kepada kreditor sesuai dengan jangka waktu yang telah disepakati atau diperjanjikan. Perjanjian utang piutang dalam kehidupan bermasyarakat hampir dapat dikatakan merupakan suatu hal yang lazim dilakukan. Hal ini dikarenakan kebutuhan yang meningkat sedangkan kondisi keuangan masyarakat tidak stabil yang mengakibatkan terjadinya perjanjian utang piutang. Data yang diperoleh dari lapangan yaitu dari beberapa daerah diKabupaten Karawang mengindentifikasi bahwa perjanjian utang piutang dilakukan secara tradisional atau sederhana. Sederhana disini memiliki makna bahwa perjanjian tersebut hanya dilakukan secara lisan atau setidaknya menggunakan kwitansi yang di dalamnya

\footnotetext{
${ }^{7}$ Ahmadi Miru, Hukum Kontrak dan Perancangan Kontrak, Rajawali Pers, Jakarta, 2016, hlm. 67 ${ }^{8}$ Ibid.
} 
menyebutkan tentang jumlah uang yang dipinjam, nama peminjam, dan juga jangka waktu kapan akan dikembalikan.

Praktik perjanjian utang-piutang yang terjadi di masyarakat ada yang diberikan pinjaman secara sukarela tanpa mengajukan jaminan kepada kreditor, ada juga yang disertai dengan jaminan. Tentu saja keberadaan jaminan dari debitor ini sangat penting bagi kreditor, karena dalam suatu perjanjian memiliki resiko terjadinya wanprestasi. dalam melaksnakan prestasi, ada kalanya seorang debitor tidak dapat melaksanakan kewajibannya. Tidak terpenuhinya kewajiban itu ada dua kemungkinan alasan yaitu:

1. Karena kesalahan debitor, baik karena kesengajaan maupun karena kelalaian.

2. Disebabkan adanya keadaan memaksa (force majeur), sesuatu yang terjadi di luar kemampuan debitor, debitor tidak bersalah. Wanprestasi atau cidera janji adalah suatu kondisi di mana debitor tidak melaksanakan kewajiban yang ditentukan di dalam suatu perikatan, khususnya perjanjian. Wanprestasi dalam hukum perjanjian mempunyai makna yaitu debitor tidak melaksanakan kewajiban prestasinya atau tidak melaksanakan sebagaimana mestinya sehingga kreditor tidak memperoleh apa yang dijanjikan oleh pihak lawan. ${ }^{9}$

\footnotetext{
${ }^{9}$ Ridwan Khairandy, op.cit, hlm.278
}

Wanprestasi merupakan suatu peristiwa atau keadaan dimana debitur tidak memenuhi kewajiban prestasi perikatannya dengan baik. ${ }^{10}$ Ketentuan mengenai Wanprestasi diatur pada Pasal 1238 KUHPerdata yang menyatakan bahwa "Si berutang adalah lalai, apabila ia dengan dinyatakan lalai, atau demi perikatannya sendiri, ialah jika ini menetapkan, bahwa si berutang harus dianggap lalai dengan lewatnya waktu yang ditentukan". Sedangkan di dalam Pasal 1243 KUHPerdata menyatakan "Penggantian biaya, kerugian, dan bunga karena tak dipenuhinya suatu perikatan, barulah mulai diwajibkan, apabila si berutang, setelah dinyatakan lalai untuk memenuhi perikatan itu, tetap melalaikannya, atau jika sesuatu yang harus diberikan atau dibuatnya, hanya dapat diberikan atau dibuatnya dalam tenggang waktu yang telah dilampaukannya".

Pada dasarnya setiap kontrak (perjanjian) yang dibuat para pihak harus dapat dilaksanakan dengan sukarela atau iktikad baik, namun dalam kenyataannya kontrak yang dibuatnya seringkali dilanggar. ${ }^{11}$ Fenomena yang terjadi di masyarakat ketika terjadi wanprestasi beberapa kreditor saat akan menagih prestasi kepada debitor menggunakan ancaman atau menakuti debitor bahwa jika tidak segera melaksanakan prestasi akan dilaporkan kepada pihak kepolisian.

10 J. Satrio, Wanprestasi Menurut KUHPerdata, Doktrin, Dan Yurisprudensi, PT. Citra Aditya Bakti, Bandung, 2012, hlm.2

${ }^{11}$ Salim H.S., op.cit, hlm. 140 
Seperti yang telah dijelaskan sebelumnya di atas bahwa memang ditemukan beberapa kasus wanprestasi dilaporkan kepada pihak kepolisian.

Perbuatan Debitor sebagai pihak yang melakukan wanprestasi dapat dikatakan sebuah kesalahan, karena dalam hukum perjanjian atau kontrak terdapat asas pacta sunt servanda yang artinya bahwa perjanjian itu harus dipatuhi layaknya seperti undangundang bagi mereka yang membuatnya. Namun meski demikian debitor juga tetap harus mendapatkan perlindungan hukum sehingga tidak mendapatkan perlakuan yang tidak semestinya. Jika debitor melakukan wanprestasi namun debitor tersebut menunjukkan iktikad baik kepada kreditor dengan berniat untuk melaksanakan prestasi, maka sebaiknya diselesaikan secara musyawarah atau kekeluargaan saja. Dalam hukum kontrak, debitor dapat dikenakan bunga jika terlambat melaksanakan prestasi.

Dalam perspektif hukum perdata, tidak dibenarkan bagi kreditor memaksakan pemenuhan prestasi dari debitor dengan cara melaporkannya kepada pihak kepolisian atau dengan membawa polisi ketika menagih prestasi kepada debitor. Urusan utang piutang adalah murni hubungan keperdataan sebagaimana yang diatur di dalam KUHPerdata, sehingga mekanisme penagihannya harus sesuai dengan ketentuan yang berlaku. segala bentuk penagihan utang yang dilakukan oleh anggota kepolisian sangat bertentangan dengan undang-undang Kepolisian dan Peraturan Disiplin Kepolisian.

Mekanisme dalam pemyelesaian kasus wanprestasi ada 2 (dua) cara, yaitu melalui pengadilan (litigasi) dan penyelesaian di luar pengadilan (non litigasi).

\section{Penyelesaian melalui jalur Litigasi}

Litigasi merupakan suatu proses gugatan, suatu sengketa diritualisasikan yang menggantikan sengketa sesungguhnya, yaitu para pihak dengan memberikan kepada seorang pengambil keputusan dua pilihan yang bertentangan. ${ }^{12}$ Penggunaan sistem litigasi mempunyai keuntungan dan kekurangan dalam penyelesaian suatu sengketa. Keuntungannya yaitu: ${ }^{13}$

a) Dalam mengambil alih keputusan dari para pihak, litigasi sekurangkurangnya dalam batas tertentu menjamin bahwa kekuasaan tidak dapat mempengaruhi hasil dan dapat menjamin ketentraman sosial;

b) Litigasi sangat baik sekali untuk menemukan berbagai kesalahan dan masalah dalam posisi pihak lawan;

c) Litigasi memberikan suatu standar bagi prosedur yang adil dan memberikan peluang yang luas kepada para pihak untuk didengar keterangannya sebelum mengambil keputusan;

\footnotetext{
12 Ibid, 141

${ }^{13}$ Ibid.
} 
d) Litigasi membawa nilai-nilai masyarakat untuk penyelesaian sengketa pribadi;

e) Dalam sistem litigasi para hakim menerapkan nilai-nilai masyarakat yang terkandung dalam hukum untuk menyelesaikan sengketa.

Yahya Harahap mengemukakan bahwa penyelesaian sengketa melalui lembaga peradilan dinilai kurang efektif, karena: ${ }^{14}$

a) Penyelesaian perkara yang lambat dan banyak membuang waktu;

b) Biaya mahal;

c) Peradilan tidak responsif terhadap kepentingan umum;

d) Putusan pengadilan tidak menyelesaikan sengketa;

e) Kemampuan hakim bersifat generalis;

f) Putusan pengadilan seringkali dijatuhkan tidak disertai dengan pertimbangan yang cukup rasional.

Dari uraian di atas dapat kita ketahui bahwa penyelesaian sengketa melalui pengadilan terdapat kelemahan dan kelebihan. Dalam kasus wanprestasi perjanjian utangpiutang yang terjadi di masyarakat, menurut hemat penulis tidak disarankan menyelesaikan melalui jalur pengadilan atau litigasi. Hal ini dikarenakan proses penyelesaian sengketanya tidak efisien dan efektif. Selain itu penyelesaian sengketa di pengadilan akan membutuhkan waktu yang lama dan biaya

14 M. Yahya Harahap, Hukum Acara Perdata, Sinar Grafika, Jakarta, 2006,hlm.14 yang mahal. Meskipun dalam hukum acara di pengadilan terdapat asas "sederhana, cepat, dan biaya ringan". Penyelesaian sengketa di pengadilan merupakan "ultimum remidium" atau upaya terakhir dalam mencari kebenaran.

\section{Penyelesaian melalui jalur non Litigasi}

Penyelesaian melalui jalur non litigasi merupakan penyelesaian sengketa di luar jalur pengadilan atau biasanya disebut Alternative Dispute Resolution (ADR). Cara penyelesaian sengketa melalui ADR antara lain negosiasi, mediasi, arbitrase. Ketentuan mengenai ADR ini diatur dalam UU No. 30 Tahun 1999 tentang Arbitrase dan Alternatif Pilihan Penyelesaian Sengketa. Dalam penyelesaian sengketa tentunya membutuhkan penyelesaian yang terbaik, cepat, efektif dan efisien.

Dalam penyelesaian sengketa wanprestasi perjanjian utang-piutang yang terjadi di masyarkat, maka akan lebih baik diselesaikan melalui jalur non litigasi karena ini merupakan pola yang ideal dan memberikan win-win solution bagi para pihak. pola penyelesaian ini dianggap terbaik karena:

a) Bersifat informal;

b) Biayanya murah;

c) Penyelesaian cepat;

d) Menyelesaiakan sengketa dan memperbaiki hubungan di antara para pihak yang bersengketa;

e) Keputusan yang didapat adalah win-win solution. 
Pilihan penyelesaian sengketa mengenai perjanjian utang piutang berdasarkan ADR, negosiasi adalah penyelesaian yang paling tepat untuk menyelesaikan masalah tersebut. Negosiasi sebagai salah satu alternatif penyelesaian sengketa merupakan sarana bagi para pihak untuk mendiskusikan permasalahannya tanpa keterlibatan pihak ketiga. Artinya penyelesaian dilakukan oleh dua pihak yang bersengketa. Dalam kasus wanprestasi perjanjian utang piutang yang kebanyakan perjanjian tersebut awalnya dilakukan oleh masyarakat melalui cara yang sederhana, sehingga jika terjadi perselisihan alangkah baiknya jika diselesaikan dengan cara yang baik pula. Syarat utama yang harus dimiliki oleh para pihak adalah adanya "iktikad baik". jika kedua pihak memiliki iktikad baik maka akan semakin mudah dan terbuka penyelesaian sengketa melalui jalur negosiasi agar menghasilkan keputusan yang win-win solution. Tanpa adanya iktikad baik, akan sulit untuk diselesaikan melalui jalur negosiasi. Keuntungan penyelesaian sengketa melalui negosiasi tentunya akan menjaga hubungan baik kedua pihak untuk ke depannya.

\section{KESIMPULAN}

Berdasarkan hasil penelitian dan pembahasan maka dapat disimpulkan penelitian ini sebagai berikut:

1. Debitor akan mendapatkan perlindungan hukum dari ancaman hukum pidana apabila pada saat melakukan negosiasi kepada kreditor dalam hal utang piutang pertama kali tidak menggunakan nama palsu, martabat palsu, maupun tipu daya sebagaimana yang dimaksud dalam Pasal 378 KUHP tentang Penipuan. Sehingga debitor tidak perlu takut akan dipenjara akibat wanprestasi atau tidak dapat melunasi utang sebagaimana jangka waktu yang telah ditentukan. Jika terjadi wanprestasi debitor harus menunjukkan iktikad baik bahwa akan menyelesaikan prestasi kepada kreditor.

2. Penyelesaian sengketa dalam kasus wanprestasi perjanjian utang piutang dapat dilakukan melalui 2 (dua) cara, yaitu dapat melalui jalur litigasi (pengadilan), maupun jalur non litigasi (di luar pengadilan). Penyelesaian yang ideal untuk menyelesaikan kasus wanprestasi perjanjian utang piutang adalah menggunakan cara negosiasi yang dilakukan oleh para pihak. negosiasi dapat dikategorikan diselesaikan secara kekeluargaan. Namun apabila para pihak tidak mendapatkan titik temu maka barulah diselesaikan di Pengadilan sebagai upaya terakhir. 
Perlindungan Hukum Terhadap Debitor Yang Wanprestasi Dalam Perjanjian Utang Piutang Dari Ancaman Pidana: Muhammad Gary Gagarin Akbar dan Zarisnov Arafat

\section{DAFTAR PUSTAKA}

Ahmadi Miru, Hukum Kontrak dan Perancangan Kontrak, Rajawali Pers, Jakarta, 2016.

Gatot Supramono, Perjanjian Utang Piutang, Kencana Prenada Media Group, Jakarta, 2013.

Hendry P. Panggabean, Penyalahgunaan Keadaan (Misbruik van Omstandigheiden) Sebagai Alasan Baru Untuk Pembatalan Perjanjian (Berbagai Perkembangan Hukum di Belanda), Liberti, Yogyakarta, 2001.

M.Yahya Harahap, Segi-Segi Hukum Perjanjian, Alumni, Bandung, 1986.

P.A.F. Lamintang dan Theo Lamintang, Delik - Delik Khusus Kejahatan Terhadap Harta Kekayaan, Sinar Grafika, Jakarta, 2009.

Ridwan Khairandy, Hukum Kontrak Indonesia Dalam Perspektif Perbandingan (bagian Pertama), FH UII Press, Yogyakarta, 2013.

Salim, Teori dan Teknik Penyusunan Kontrak, Sinar Grafika, Jakarta 2015.

Subekti, Aneka Perjanjian, Citra Aditya Bakti, Bandung, 2014.

\section{Peraturan Perundang-undangan}

Kitab Undang-Undang Hukum Perdata

Kitab Undang-Undang Hukum Pidana

Undang-Undang Nomor 20 Tahun 1999 tentang Arbitrase dan Alternatif Pilihan Penyelesaian Sengketa. 